The Carnegie data offer important information about how institutions allocate funding for engagement and develop marketing and fundraising campaigns to support engagement activities.

\title{
Engagement and Institutional Advancement
}

\author{
David Weerts, Elizabeth Hudson
}

Research suggests that institutional commitment to community engagement can be understood by examining levels of student, faculty, and community involvement in engagement; organizational structure, rewards, and campus publications supporting engagement; and compatibility of an institution's mission with this work (Holland, 1997). Underlying all of these factors is campus financial commitment to engagement and whether engagement is reflected as a budget priority and key component in resource development campaigns.

This chapter examines ways in which engaged institutions allocate internal resources to support engagement and how these campuses have reshaped their institutional advancement programs (marketing, branding, and fundraising activities) to leverage financial support for engagement. We begin with a brief literature review discussing the relationship between advancement and engagement, followed by a formal investigation of how engaged institutions have approached resource development to support engagement programs. All colleges and universities discussed as engaged institutions in this chapter are recipients of the Carnegie Foundation's elective classification in curricular engagement and outreach and partnerships (Carnegie Foundation for the Advancement of Teaching, 2008).

\section{Advancement in an Era of Engagement}

Fundraising for public engagement programs has gained momentum, especially in the area of service-learning. Campus Compact (2004), a national coalition of over a thousand college presidents committed to engagement, 
has documented over seventy endowed centers for community and public service centers. Its guide suggests that institutions that have been successful in raising endowed funds for service programs share several characteristics: they have politically and civically active student bodies; enjoy strong support from administrators (especially presidents), alumni, and the campus development office; and operate service programs that are compatible with the vision, mission, curriculum, and goals of the institution.

More recently, traditional advancement practices are being reconsidered in light of the emerging emphasis on community engagement in higher education (Weerts, 2007). This may be fueled in part by research suggesting that today's higher education donors are less likely to give to advance institutional goals and more likely to give if their support yields tangible community outcomes (Strickland, 2007). In short, today's donors are motivated by giving opportunities that will make an impact on society (Grace and Wendroff, 2001).

Consistent with the desires and expectations of today's philanthropists, engaged institutions such as Portland State University have been highly successful in raising private funds for programs that are mutually beneficial to the campus and community. Engagement guides its goal setting, budgetary decision making, and priorities for its current capital campaign (Langseth and McVeety, 2007). And at major research universities, leveraging private support for public engagement fits squarely with federal grants programs that increasingly fund research on their merits in serving broad societal needs (Bloomfield and Wittkoff Kuhl, 2007).

Increasingly engagement has become part of the identities of these institutions, and the engagement brand has been leveraged to increase public support for these campuses. In particular, engagement as an institutional brand has been advanced to cultivate legislative support for higher education (Blanton, 2007). In addition, studies have shown a link between institutional commitment to outreach and engagement and increases in levels of state appropriations for research universities (Weerts and Ronca, 2006). Simply put, across all campus missions, engagement provides a platform to cultivate diverse revenue streams from private and public sources.

\section{Advancement Practices at Engaged Institutions}

To better understand budgeting and advancement practices at engaged institutions, we analyzed applications from a representative sample of U.S. colleges and universities receiving the Carnegie Foundation's elective classifications in curricular engagement and outreach and partnerships (Carnegie, 2008). We selected institutions for investigation by authority and control (public or private), geographical region (urban or rural), and mission (research or teaching oriented). Table 7.1 lists the institutions in our sample.

Because institutional advancement concepts were integrated throughout each application, we open-coded (Strauss and Corbin, 1990; Jones, Torres, and Arminio, 2006) the entire document to capture relevant data. 
Table 7.1. Institutions Examined in the Sample

\begin{tabular}{|c|c|c|c|c|}
\hline $\begin{array}{l}\text { Land-Grant } \\
\text { Universities } \\
\text { (Suburban or } \\
\text { Rural Areas) }\end{array}$ & $\begin{array}{c}\text { Private Research } \\
\text { Universities (Large } \\
\text { Metropolitan Areas) }\end{array}$ & $\begin{array}{c}\text { Comprehensive } \\
\text { Public } \\
\text { Universities }\end{array}$ & $\begin{array}{l}\text { Private } \\
\text { Liberal } \\
\text { Arts } \\
\text { Colleges }\end{array}$ & $\begin{array}{c}\text { Associate's } \\
\text { Colleges }\end{array}$ \\
\hline $\begin{array}{l}\text { North } \\
\text { Carolina State } \\
\text { University }\end{array}$ & Emory University & $\begin{array}{l}\text { Morehead State } \\
\text { University }\end{array}$ & $\begin{array}{l}\text { Rhodes } \\
\text { College }\end{array}$ & $\begin{array}{l}\text { Bristol } \\
\text { Community } \\
\text { College }\end{array}$ \\
\hline $\begin{array}{l}\text { Michigan State } \\
\text { University }\end{array}$ & $\begin{array}{l}\text { University of } \\
\text { Pennsylvania }\end{array}$ & $\begin{array}{l}\text { California State } \\
\text { University-Fresno }\end{array}$ & $\begin{array}{l}\text { Bates } \\
\text { College }\end{array}$ & $\begin{array}{l}\text { Chandler/ } \\
\text { Gilbert } \\
\text { Community } \\
\text { College }\end{array}$ \\
\hline $\begin{array}{l}\text { Virginia Tech } \\
\text { University }\end{array}$ & Tufts University & $\begin{array}{l}\text { Western } \\
\text { Kentucky } \\
\text { University }\end{array}$ & $\begin{array}{l}\text { Wartburg } \\
\text { College }\end{array}$ & $\begin{array}{l}\text { Middlesex } \\
\text { Community } \\
\text { College } \\
\text { (Massachusetts) }\end{array}$ \\
\hline
\end{tabular}

Note: Land grant institutions: 1862 designated institutions, strong agricultural tradition in rural and suburban areas (very high research activity). Private research universities: private research institutions near or in major metropolitan areas (very high research activity). Comprehensive public universities: master's colleges and universities (larger programs). Private liberal arts colleges: fouryear, private, baccalaureate colleges, arts and sciences focus. Associate's colleges: Associate degrees, public urban-serving campus.

Our analysis is limited by the type and number of application questions asked and how applicants interpreted and chose to respond to those questions. We also acknowledge that institutions vary in their capacity to support engagement, depending on the availability and range of revenue sources (public and private). Our analysis should be read with this in mind. Responses to the following application questions yielded the most data informing our analysis:

- Are there internal budgetary allocations dedicated to supporting institutional engagement with community? Provide evidence.

- Is there external funding dedicated to supporting institutional engagement with community? Provide evidence.

- Is there fundraising directed to community engagement? Provide evidence.

- Is community engagement emphasized in marketing materials? Provide evidence.

\section{Findings and Discussion}

To arrive at reasonable findings and conclusions, we conducted a thematic analysis of institutional responses to each of the four questions. Our analysis suggests that institutions are "finding their own way" in financing community engagement based on their own structures, culture, mission, and histories. 
At the same time, a great deal of overlap in engagement and budgeting/ advancement practices exists across institutional types. We begin our analysis by briefly outlining how institutions allocate internal resources for engagement and then shift our emphasis to articulate how engagement relates to marketing and fundraising practices on these campuses.

Internal Financial Commitment. All of the institutions analyzed in our study demonstrated some level of internal commitment to fund engagement, broadly defined. In many cases, centralized administrative offices were set up to provide a clearinghouse for funding opportunities and provide a mechanism to manage this process. The scope and type of commitment to funding engagement vary somewhat by institutional mission, size, and how the campus collectively "makes sense of" engagement within its unique culture and setting. However, among all institutions, studentcommunity engagement programs (such as service-learning) were a primary starting point for campuses to discuss engagement as a funding priority. That is, support for engagement largely focused on developing curriculum and student learning around civic themes. Furthermore, internal funds were often tightly coupled with a range of external grants (such as those of the AmeriCorps Vista Program) supporting a variety of activities and programs related to student learning, civic engagement, and student research opportunities.

Engagement budgets typically include staff salaries and benefits, student programs, supplies, and professional development for faculty and staff. Among all the institutions we studied, liberal arts colleges and community colleges appear to have the most seamless path of integration for financially supporting this work due to their emphasis on teaching and civic leadership. Wartburg College, when including its service-learning and curricular programs, spent nearly $\$ 1$ million on engagement. And more than 2 percent of the Bates College operating budget goes to its service-learning center and public programming. In its budget, Rhodes College provides support for several diverse engagement programs such as Up Till Dawn, a student-run fundraising effort for a community hospital, and Rhodes CARES, an undergraduate research and service program.

Community colleges in our sample, such as Middlesex Community College, allocated percentages of their budget to engagement. In 2005-2006, the Middlesex Division of Social Science and Human Services spent approximately $\$ 6.8$ million, or 16.2 percent of its total budget, on engagement-related expenses, not including additional funds for professional development. Furthermore, a portion of its student activities budget is used to promote civic engagement through college clubs, events, and an array of cocurricular activities.

Overall, private liberal arts colleges and community colleges are particularly well poised to provide institutional support for engagement through the lens of service-learning or student engagement programs. Since 
many of these campuses have a strong civic or teaching aspect to their missions, engagement programs are deeply embedded within the core teaching and learning philosophies of these institutions.

Not surprisingly, the budgets and range of internal support for engagement at research universities were larger and more complex. For example, Michigan State University has a general fund that supports the Office of University Outreach and Engagement with an annual budget of $\$ 3.6$ million. This office houses much of the institution's engagement efforts, including activities of the National Center for the Study of University Engagement and the Center for Civic Engagement and Service Learning. Because of the varied aims and decentralization of engagement activities at research university campuses, funding for engagement at these institutions is complex, and the lines between internal and external streams of support are blurred. For this reason, it is difficult to calculate precise budgets for engagement. In an effort to quantify expenditures on engagement, Michigan State leaders calculated a salary investment of nearly $\$ 20$ million for faculty and academic staff who reported their work related to outreach and engagement (calculated as full-time equivalent hours).

Finally, our analysis suggests that many campuses also support engaged scholarship in the form of internal seed grants. This practice is especially prevalent at research institutions. However, regional institutions such as Cal State-Fresno also provide mini-grants to faculty who connect scholarly activity with service-learning and civic engagement. In addition, one liberal arts institution, Bates College, offered competitive grants for publicly engaged scholarship through the Harward Center for Community Partnerships. In some cases, these internal grants were aimed at leveraging additional external funds for research.

Fundraising Efforts. Historically, elite private colleges have led the way in securing large gifts for higher education, so it is not surprising that these institutions are also leading the way in securing funding for engagement. The highest-profile example of raising private support for engagement programs is Tufts University, which recently secured a $\$ 40$ million gift for its College of Citizenship and Public Service, now named for the Tisch family who provided the gift. Tufts leaders explain, "This gift is the third largest in Tufts" history and will ensure that students graduate from Tufts prepared to be active citizens in their communities and leaders engaged in addressing core issues facing society." The Tufts example, as illustrated in our data, is representative of many campus fundraising efforts that are college specific. The Tisch endowment funds a particular college focused on citizenship, and this gift may or may not be integrated with larger engagement efforts across the university.

Private liberal arts colleges have also made gains in developing fundraising agendas for engagement. Typically these efforts focus on student aspects of engagement such as service-learning. For example, in 2006, Wartburg College successfully completed an ambitious campaign of nearly $\$ 100$ million that, 
among other campus priorities, supported community service and servicelearning programs on the campus. In rare cases, small liberal arts colleges have woven their message of engagement into educational themes of philanthropy and citizenship. Bates College is particularly innovative in this domain. The college was one of the few institutions that have highlighted community work with alumni and other partners as potential funding relationships. Specifically, the Harward Center, the college's service-learning and community research center, teams with members of institutional advancement to identify and pursue fundraising opportunities relevant to their engagement efforts, for example, a National Day of Service where students and alumni collaborate to participate in community work. Bates College staff write, "While this kind of work is not immediately linked, at the time, to fund-raising for community engagement, it is part of a strategy of communications and involvement that is intended to raise giving for community engagement." In our analysis, liberal arts colleges were more likely to incorporate leadership development training with fundraising efforts.

Like the private liberal arts colleges, community colleges were most likely to align their fundraising efforts in the domain of service-learning. In some cases, however, community colleges relied on students themselves to raise support for engagement. On these campuses, students are finding ways to support their own projects and often are recognized by institutions for the work they do to this end. The application from Chandler Gilbert Community College illustrated the limited capacity of community colleges to raise money for these efforts: "As a small community college we do not have a dedicated development office for fundraising of this type. However, the campus participates in various co-curricular and extracurricular fundraising activities as part of our service-learning and community service events." Like students in liberal arts colleges, community college students were active in fundraising drives that benefited community-based organizations.

Land grant institutions are also making strides in raising support for engagement. At Virginia Tech, the current campaign casebook seeks a fundraising goal of $\$ 5$ million to support engagement. North Carolina State embarked in 2005 on the ACHIEVE! Campaign with its $\$ 1$ billion target fundraising goal. Of that goal, $\$ 88$ million is geared to support extension and engagement scholarship and programs. At North Carolina State and many other institutions, fundraising directed to community engagement is often programmatic in nature, involving a partnership of the private sector, governmental sector, and the university.

Fundraising efforts for engagement are also under way at public comprehensive institutions. At Western Kentucky University, for example, one primary goal is to secure funding to renovate Van Meter Auditorium, a venue for performing arts and cultural and social events that bring together campus and community. In addition, the university's Kelly Autism Program was established with a private gift, and a second gift for the program has secured the financial resources necessary for its continuing operation. 
In sum, the fundraising efforts of the fifteen institutions around engagement are wide reaching and diverse. In only a few cases, however, do the community engagement efforts of institutions relate closely with the institution's development office. Rather, fundraising for engagement is largely program specific and occurs within the departments or colleges for which engagement is a priority. Alternatively, students are also involved as fundraisers for engagement, but largely to the benefit of community organizations and their own leadership development. Rarely are student fundraising efforts connected to larger advancement efforts around engagement.

Marketing and Branding Engagement. Institutional fundraising efforts are clearly linked to campus marketing and branding activities. The institutions in our sample deliberately tout engagement as part of their institutional identity, as engagement is referenced heavily through external and internal media. Interestingly, we note that institutional marketing efforts were just as focused on bolstering internal support for engagement as external support. Internally, institutions discussed marketing for engagement as communications that focused on articulating civic engagement opportunities for current and potential students. For example, Emory University publishes a student brochure, "The Roadmap to Community Service," aimed at assisting undergraduate students who are interested in serving in the greater Atlanta community.

Overall, institutions employ a mix of marketing strategies to reach various internal and external audiences. Campus newsletters, alumni magazines, student handbooks, admission's viewbooks, and scholarship materials all sought to reinforce the theme of engagement at these institutions. The private institutions in our analysis typically had the most sophisticated and far-reaching communications materials articulating the civic activities of the campus. For example, the Rhodes alumni magazine carries frequent stories about Rhodes' civic engagement initiatives, and the University of Pennsylvania typically embeds engagement into its alumni communications. Penn writes in in its Carnegie application, "Penn's engagement activities are underscored in its alumni publications and have been emphasized at numerous alumni events." Furthermore, both Bates College and Wartburg College have an awards program to recognize alumni who exhibit outstanding service to their communities.

Differences in marketing engagement across institutions depend on the marketing capacity and the size and scope of the targeted audience. For example, in some cases, the institution's radio station is identified as a marketing agent, while other campuses must rely more heavily on local newspapers to publish news about the institution's work in the community. Some institutional applicants in our sample suggested that much of the external marketing for engagement focuses on building relationships with key stakeholders who benefit from and collaborate on engagement activities. Especially at major research universities, institutional leaders are frequently invited by government officials to make presentations on the institution's involvement in statewide, national, or international ventures. 
As researchers, we observe that many of the larger institutions, both private and public, appear to be vying for space in the national and international spotlight of top engaged institutions. Private universities such as Penn and Tufts are likely to first position their work in a national and international context and then relate this to a local setting as well. Land grant institutions also view themselves in a national and international arena, but they are mindful about their primary responsibility to focus on the needs of their states. Alternatively, comprehensive institutions and community colleges may focus closely on regional constituents to show their presence in serving a geographical area. Finally, liberal arts institutions may seek to position their engagement brand to bolster their reputations as leaders in providing liberal education. Overall, we conclude that the ways in which institutions market engagement have a great deal to do with how they see themselves and define their key constituencies.

Campus presidents may be the most important marketing tools to shape the civic identities of these campuses. In Chapter Two in this volume, Sandmann and Plater articulate this point in depth, and we briefly reinforce the notion that presidential communication (on and off campus) is critical to reinforce the engagement brand. For example, we noted instances of campus presidents testifying before state legislatures on engagement (Morehead State University), at faculty assembly meetings (CSU-Fresno), and at Founder's Days (Virginia Tech). But the most powerful marketing strategy is evident through presidential behavior. For example, at Chandler/Gilbert Community College, President Maria Hesse actively participates in a broad range of business and community advisory councils and is a highly visible spokesperson for the role of the college as an active community partner. At Middlesex Community College, President Carole Cowan sits on over twenty community boards.

\section{Conclusion}

We conclude with several observations that inform our understanding of budgetary support for engagement and advancement efforts to support this work. First, student aspects of engagement are consistently present and promoted in fundraising efforts across all of the institutions we studied. Even at the major research universities where scholarship is paramount, student learning and civic engagement holds a prominent place on the institution's engagement agenda. In all cases, internal funding is largely supplemented by an array of grants from diverse public and private sources. Together these funds constitute the primary engagement budgets on these campuses.

Second, institutions have developed elaborate marketing strategies to communicate their unique brand of engagement. These brands are compatible with the culture and mission of each institution and help campuses communicate their values to diverse groups of internal and external constituents. At the same time, engagement is shaping and reshaping the 
culture of these campuses. Put simply, institutional boundaries are expanding to accommodate this emerging campus priority, and engagement is becoming part of the fabric of these organizations. Interestingly, we note the importance of the language used to describe engagement activities on campuses. Institutions are using many different words to talk about engagement, broadly defined. Our finding supports other studies suggesting that various engagement dialects develop around disciplines or campus cultures (Diamond and Adam, 2004; Wergin, 2006). In the case of advancement, it appears that institutions settle on a set of engagement terms that are most compatible with their mission and culture. In the end, campus presidents are primary marketers of engagement in both rhetoric and practice, and they can have a strong influence on the language that is used in this context.

Third, in the area of fundraising, campuses of all types are beginning to ramp up efforts to secure private gifts for engagement. Elite private institutions have a head start on raising money for engagement, mostly likely since they already have a sophisticated machinery to identify, cultivate, and solicit potential donors. Overall, however, fundraising for engagement is in its infancy and has yet to be fully integrated into campus priorities for funding. This is especially true at community colleges, where advancement is a relatively new enterprise, especially in the area of engagement. To date, engagement has not made its way fully into development offices as an institutional strategy to raise support.

What are the implications of our analysis for research and practice? Clearly, the topic of community engagement and its relationship to institutional advancement is ripe for additional research. As institutional budgets tighten, engagement offices will rely more heavily on alternative revenue streams to sustain their programs. Strong advancement programs are critical to providing resources for engagement, and new models must be developed and tested to provide mutually beneficial outcomes for both campuses and the communities they serve. Many questions remain about the implications of the growing engagement movement and its partnership with development offices. This chapter merely identifies themes from what administrators chose to include in their application; additional research on this topic can provide promising contributions to the fields of engagement and advancement.

Finally, our analysis suggests some important implications for institutional leaders. In particular, the potential benefits of collaboration between leaders of engagement and advancement are enormous; however, these connections remain largely unexplored. Engagement provides an excellent opportunity for institutions to reconsider the ways in which they relate to important external stakeholders: alumni, donors, legislators, and the public at large. We suggest that if marketing and fundraising are coupled with authentic institutional efforts to engage with community, the opportunities for raising support for institutions are tremendous. Institutional mission should be a compass that guides discussions about engagement and institutional advancement strategies. 


\section{References}

Blanton, J. "Engagement as a Brand Position in the Higher Education Marketplace." International Journal of Educational Advancement, 2007, 7, 143-154.

Bloomfield, V. A., and Wittcoff Kuhl, M. "Institutional Advancement and Public Engagement in the STEM and Health Science Disciplines." International Journal of Educational Advancement, 2007, 7, 131-142.

Campus Compact. The Service and Service-Learning Guide to Endowed Funding. Providence, R.I.: Campus Compact, 2004.

Carnegie Foundation for the Advancement of Teaching, "Community Engagement Elective Classification." 2008. Retrieved February 20, 2008, from http://www.carnegiefoundation. org/classifications/index.asp?key $=1213$.

Diamond, R. M., and Adam, B. E. "Balancing Institutional, Disciplinary, and Faculty Priorities with Public and Social Needs: Defining Scholarship in the 21st Century." Arts and Humanities in Higher Education, 2004, 3(1), 29-40.

Grace, K. S., and Wendroff, A. L. High Impact Philanthropy: How Donors, Boards, and Nonprofit Organizations Can Transform Communities. Hoboken, N.J.: Wiley, 2001.

Holland, B. A. "Analyzing Institutional Commitment to Service: A Model of Key Organizational Factors." Michigan Journal of Community Service Learning, 1997, 4, 30-41.

Jones, S. R., Torres, V., and Arminio, J. Negotiating the Complexities of Qualitative Research in Higher Education: Fundamental Elements and Issues. New York: Routledge, 2006.

Langseth, M. N., and McVeety, C. S. "Engagement as a Core University Leadership Position and Advancement Strategy: Perspectives from an Engaged Institution." International Journal of Educational Advancement, 2007, 7, 117-130.

Strauss, A., and Corbin, J. Basics of Qualitative Research: Grounded Theory Procedures and Techniques. Thousand Oaks, Calif.: Sage, 1990.

Strickland, S. "Partners in Writing and Rewriting History: Philanthropy and Higher Education." International Journal of Educational Advancement, 2007, 7, 104-116.

Weerts, D. J. "Toward an Engagement Model of Institutional Advancement at Public Colleges and Universities." International Journal of Educational Advancement, 2007, 7, 79-103.

Weerts, D. J., and Ronca, J. M. "Examining Differences in State Support for Higher Education: A Comparative Study of State Appropriations for Research Universities." Journal of Higher Education, 2006, 77(6), 935-965.

Wergin, J. F. "Elements of Effective Community Engagement." In S. L. Percy, N. L. Zimpher, and M. J. Brukhardt (eds.), Creating a New Kind of University: Institutionalizing Community-University Engagement. San Francisco: Anker/Jossey-Bass, 2006.

DAVID WEERTS is assistant professor in the Department of Educational Policy and Administration at the University of Minnesota.

ElizABETH HUdSON is a doctoral student in the Center for the Study of Higher and Postsecondary Education at the University of Michigan and a graduate assistant at the National Forum on Higher Education for the Public Good. 